\title{
ISLAMIC THOUGHTS ON SOCIETAL PLANNING \& MANAGEMENT
}

Dr. Akef M.A. Quazi

Universiti Teknologi Malaysia

Preface

This conference has undertaken to examine The Islamic Approach to Technological Development. Technological development has two dimensions - the hardware and the software. I have chosen to look into the realm of Islamic 'software' in terms of development particularly societal development. The 'software' here would include some of the basic tenets of Islam, and social thoughts of some Muslim scholars as inspired by the Islamic ideology.

I cannot claim to be an original researcher on Islamic tenet, principles and values, nor do I dare offer any new interpretation of those. Much of the materials in this paper are based on absorbing works of other Muslim scholars. What I have tried to achieve in this paper is to present a platform consisting of thoughts of some of the prominent Muslim thinkers of the past and the present, which appeal to me as very relevant for societal planning, and on which other Muslim thinkers, leaders, and planners may like to give further thoughts. Whenever I have referred to Islamic tenets on my own accord, are those which, I trust, are common knowledge to all Muslims.

My hopes and aspiration in writing this paper has been that Muslims by faith are members of one community; - we should not land ourselves into any controversy, rather on the contrary - this conference should serve as one of the sources of intellectual unity, and pave the way for us to forge ahead as a world community of harmony, peace, progress and leadership.

\section{Introduction}

The Messenger of Islam (s.a.w.) arrived at a time when the world was full of spiritual and social confusion. The Devine Wisdom ordained in Prophet Muhammad (s.a.w.) aptly recognized that the spiritual confusion and social confusion was mutually causative. To a splintered community Islam offered a comprehensive solution that was not befitting to the societal problems and spiritual problems. The Prophet (s.a.w.) taught the new community which grew around him how to live a spiritual as well as social life, how to organize, consolidate and stabilize the Community of Believers, and be effective in its purpose through united submission to the Supreme One. The Prophet directed a great deal of his physical and spiritual energy towards bringing harmony in social relations, social integration and unity. A new rela- 
tionship between man and society beyond the strictly defined limits of the family or tribe was established and a new purpose was given to human existence. With an intelligible explanation of the Devine Oneness of His 'Grand Design', Muhammad (s.a.w.) enables human beings to relate the inner self and the outer-reality as well as the ultimate human purpose, and thus he has cast the mould for an organised community for the progeny of Adam.

In these days of societal pluralism of the rich and the poor, the conservative and the modern, of ethic separatism, and the diversity of ism, one has to reflect on how the basic tenets and spirit of Islam succeeded in incorporating the divergent social elements which shaped its early civilization, and how the initial pluralism galvanized into a uniform and monolithic world view until the intervention of modern European ideas. The current state of pluralism make it topical to look into Islamic thoughts in respect of social relations and social integration.

\section{Islamic thoughts on Social Relations, and Social Integration. ${ }^{1}$}

The monotheism implied in the concept of Allah is far more comprehensive and all embracing than the simple etymological meaning of monotheism. In Islam oneness of Allah implies unity of life and all His creation. All things and non-things, laws of nature and laws of men, the diversity of nature and the unity of the cosmos, the multiplicity of human groups and the oneness of all mortal human beings, are all contained in the unity of Allah. The concept of Allah is so all-embracing that there cannot be any sphere of life and living outside the Divine Order of Things. In Islamic framework of life and living, the spiritual and the temporal, the sacred and the secular, the divine and the mundane, public and private cannot be held in mutually exclusive spheres. $^{2}$

The goals of human social relations and social integration are ingrained in the concept of the Supreme Oneness and the indivisibility of the Divinity. The scheme of life and human living is meant to revolve around this central concept (Tawhid). The universe, which itself is unified entity, has emanated from a single Will. Therefore humanity is meant to be an essential unity where man and his fellow men and the universe are meant to be harmonious to each other and be cooperative with one another; hence the commandment:

"And holdfast all together by the rope which Allah stretches out for you, and be not divided among yourself."

Social unity is a Divine Mandate in Islam and to this end Islam declares.... "the believers are brothers (Al-Quran; 49:10) This is the basis

\footnotetext{
${ }^{1}$ For a scholarly account on Islam and social integration see W.M. Watt, Islam and the integration of society (London, 1961).

${ }^{2}$ A. Gauhar, The challenge of Islam, (London, 1978), p. XXIII-XXV.
}

on which the first Muslim social order was established by Muhammad (s.a.w.) in Madina - a social order which spread like forest fire from the Indian Ocean to the Atlantic in short span of a century; and this is the basis which remains the fountain head of Islamic social thoughts.

At a time when the Islamic world was split by a dangerous schismatics between the Fatimids of Egypt and the Seljuq Turks (the socalled 'mainstream Muslims' of that time.) Abu Hamid Muhammad ibn Muhammad al-Tusi al-Shafii al-Ghazali (1058-1111) made the most powerful contribution to the al-Shafii al-Ghazali (1058-117 "ulum al-din (Revival of Religious Sciences) consisting of four large volumes, Al-Ghazali devoted one specially to the question of behaviour of Muslims as members of a community of believers. In this volume he hammered out the meaning and implications of brotherhood in Islamic faith as the cornerstone of social organisation and solidarity in society.

Second only to Prophet Muhammad, al-Ghazali has most convincingly put across the Divine Mandate for Muslims to commit themselves to a contract of brotherhood with fellow Muslims. He shows how brotherhood can tract of brotherhood witual help and comfort in human societal existence. Al-Ghazali conceived the whole Community of Believers as one vast social network of brotherhood, and towards that brotherhood he has this to say:

"Know that the contract of brotherhood is a bond between two persons, like the contract of marriage between two spouses. For just as marriage gives rise to certain duties which must be fulfilled when it is entered into, so does the contract of brotherhood confer upon your brother a certain ro does the contract of brour property, your person, your tongue and your heart - by way of prayer and forgiveness, sincerity, loyalty relief and considerateness" 3 ..........

"a man's belief is incomplete so long as be does not wish for his brother what be wishes for himself" 4 ....

Based on the above principle, al-Ghazali enunciates eight duties in brotherhood. ${ }^{5}$ No higher ideals of social solidarity and social integration can be served beyond that envisioned in al-Ghazali's concept of brotherhood.

The notion of cooperation as the cornerstone of any social grouping, is reiterated by another Muslim scholar Abd-ar-Rahman Abu Zayd Ibn Muhammad Ibn Khaldun (1332-1406) in his celebrated work entitled alMuqaddimah (the Introduction of World History). This work is in fact the Muqaddimah (the Introduction and civilization. first ever scientific presentation of history of societies and civilization.

Ibn Khaldun stresses that the ultimate destiny of groups, societies and civilization depends on the degree of cooperation, and that man is endowed

${ }^{3}$ On duties of brotherhood, translated by M. Holland (1975), p. 21

${ }^{4}$ Ibid. p. 40.

${ }^{5}$ For a full appreciation of the duties, interested readers should consult the text. 
by the Creator with the capacity to think which enables him in the act of cooperation. Cooperation, therefore is the rational basis of society. Full cooperation results in a complex social process called 'Tamaddun' or urban acculturization (i.e. cultural evolution) - suggest Ibn Khaldun. As soon as some kind of social organization is formed, civilization is evolved ...... and when a social organization grows more populous, a larger and better civilization follows. 6

On the question of social solidarity and its relationship with size, quality and influence of human social organization Ibn Khaldun suggests that for large and powerful states to emerge there must be some favourable factors, some incitement for the desire to cooperate on a larger scale. This calls for 'Asabiyah, a feeling of group solidarity based on group consciousness. It is this 'Asabiyah which holds a social group together, and bestows on them power, status, and permanence over time. ${ }^{7}$ A group with powerful 'Asabiyah achieves predominance over other groups. However no group can retain its superiority, nor any leader its dominant position in the group, when the initial 'Asabiyah is no longer there to sustain them. Although 'Asabiyah is most positive amongst the people of common descent, politically it may be shared by people who are in long and close contact as members of a group.

It is important to examine Ibn Khaldun's contribution in terms of social organization and solidarity in a greater detail for he was at once a theologian, a scientific historian, a political scientist, a sociologist, a social psychologist and a scholar in Jurisprudnece. He points out that 'Asabiyah must operate at different levels in a hierarchical manner in respect of societal organization. He says that ......" "even if individual tribes (micro social group) have different houses (identity) and many diverse group feelings, still there must exist a group feeling that is stronger than all the other group feelings combined, that is superior to them all and makes them subservient, and in which all the diverse group feelings coalesce, as it were, to become one greater group feeling. Otherwise, splits would occur and lead to dissension and strife."

Ibn Khaldun also points out that group feeling works in a progressive manner through a process of psychological invasion and succession. $\mathrm{He}$ says.... "Once group feeling has established superiority over people who share in it, it will, by its very nature seek superiority over people who have other group feelings, unrelated to the first, if however, one group feeling is equal and competitive to the other, the competitive group feelings will then remain even or stalemated and the potential combined social energy will remain unattainable, suggests Ibn Khaldun. "However, if one group feeling

${ }^{6}$ Ibn-Khaldun, The Muqaddimah: an introduction to history, translated by Franz Rosenthal (London, 1967), p.XI.

${ }^{7}$ It is this notion of Asabiyah which the European sociologists of modern times called the "we feeling" which is the core of social group formation. Other sociologists called it "consciousness of the kind" as the basis of formation of society.

${ }^{8}$ Ibn-Khaldun, op. cit., p. 108. overpowers the other and makes it subservient to itself, the two group feelings enter into close contact and the defeated group feeling gives added power to the victorious group feeling, which, as a result, sets its goal of superiority and domination higher than before.,"9

In order to place adequate emphasis on the pivotal need for societal solidarity Ibn Khaldun goes on to suggest that "group feeling produces the ability to defend oneself, to offer opposition, to protect oneself, and to press one's claims". 10 In Ibn Khaldun's logic group feeling does not work among the meek and docile for "meekness and docility break the vigour of group the mee are too feeling. weak to defend themselves. To prove his point lon Khaldun cites the example of the Bani Israelis who during the time of Musa had become too fragmented and weak to offer opposition and press their claims to become rulers in Syria although there was Divine Instruction for them to do so. (If Ibn Khaldun

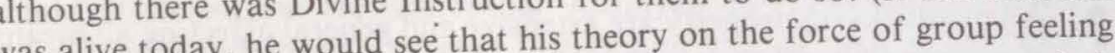
was alive today, he Bani Israelis themselves for it is the Zionist group feelis revalidated by the Bani Israelis themselves for it is the Zionist group feeling of the present Bani Israelis which has led them to set up the impossible state of Israel. Solidified group feeling can do the impossible).

However, group success and superiority, which is a product of unified colidified group feeling, may become an athema in itself, warns Ibn Khaldun. For instance, group success and the corresponding amount of Khaldun. For instance, group success and the correfree life. Their children wealth allow the group to revel in luxury and care-free life. Their children. grow up too proud to look after themselves or to attend to their own needs. They begin to disdain all other things that are necessary to sustain group feeling. This finally becomes a character trait. Their group feeling and courage decrease in the next generation. Eventually group feeling is destroyed altogether and the nation liquidates itself. "His final word on this is "the greater their luxury and the easier the life they enjoy, the closer they are to greater their lux

Ibn Khaldun's theory on 'Asabiyah has far reaching implication in all branches of societal management and planning. Through a cryptic presentabranches of societal manage tion of historical materials Ibn Khaldun highlights the pre-requisites of social stability. He pronounces that civilization inevitably suffers losses through injustice and hostile acts. By injustice he specifically mentioned the following. ${ }^{13}$ justice and hostile acts. By injustice he specificall

- Taking someone's property, or using him for forced labour, or pressing an unjustified claim against him, or imposing upon him a duty not required by religious law

- Unjustified taxes

${ }^{9}$ Ibn-Khaldun, p. 108.

${ }^{10}$ Ibn-Khaldun, p. 111.

${ }^{11}$ Ibn-Khaldun, p. 110.

${ }^{12}$ Ibn-Khaldun, p. 109.

${ }^{13} \mathrm{Ibn}-\mathrm{Kh}$ aldun, p. 240.

JURNAL TEKNOLOGI Bil. 
- Infringements upon other's right and property

- Denial of other's rights

Obviously, these are the acts of injustice which are already contained in the instructions by Prophet Muhammad (s.a.w.) admits Ibn Khaldun. However, like an astute modern economist, he further provides an economic logic for the prohibition of the above injustices. He explains: ${ }^{14}$

- Attack on people's property removes the incentive to acquire and gain property because people then become of the opinion that the purpose and the ultimate destiny of acquiring property is to have it taken away from them.

- The extent and degree to which property rights are infringed upon determines the extent and degree to which the efforts of the subjects to acquire property slacken.

- When attacks on property are extensive and general affecting all means of making all livelihood, business inactivity also becomes widespread and general.

- Civilization and its well-being as well as business prosperity depends on productivity and people's effort in all directions in their own interest and profit.

- When people no longer do business in order to make a living, and when they cease all gainful activity the business of civilization slumps, and everything decays. People scatter everywhere in search of sustenance.

- Seizure of private property by means of over-taxation, compulsory takeover, forced sale and purchases etc. all contribute to business losses and causes private funds to dwindle, which together affects trading.

- Reduced trading affects livelihood in general and also negatively affects tax revenue for the government. Thus decay starts.

Due to these evil consequences, Ibn Khaldun points out, religious laws (the Shariah) have prohibited unfair and unjust practices. Religious laws approve tacitly the use of cunning in trading, he maintains, but forbids depriving people of their property illegally.

It is worthwhile to point out in the passing that long before Adam Smith, the so called father of economics, Ibn Khaldun gave the world the theory of wealth and its creation. Long before Lord Keynes, or Milton Friedman, Ibn Khaldun spoke on the cash flow and multiplier theory, and long before Marx, Ibn Khadun propounded that "labour belongs to things that constitute capital....gain and sustenance represents the value realized from labour among civilized people;..... by their efforts and all their labours they acquire capital and make a profit;......they have no other way to make a profit except through labour", 15

\footnotetext{
${ }^{14}$ Ibn-Khaldun, p. 238-241.
}

${ }^{15}$ Ibn-Khaldun, p. 241.
In a strong tone of Islamic ideology and value, Ibn Khaldun advocates for a planned moderation in expenditure both public and private spheres of society. He emphasizes his point arguing that ...."display of wealth and luxury, pomp of power and limitless ostentation at the top echelon of society creates a chain reaction down the line and permeates all levels of society.... people then compete with each other in matters of material consumption and the new generation grow up accustomed to this situation .... the chain reaction feeds on itself and grows.... the need for more wealth and higher luxury sets in ..... the process goes on until it becomes unsustainable and the society falls to decay when any attempt to reverse the process is only futile." 16

Within the framework of his central concern for 'Asabiyah and social. solidarity, Ibn Khaldun has also provided guidelines for general societal administration and law. He assures that 'Asabiyah can crystalize into common subservience and group obedience to common code of conduct and central authority. However, he warns that this subservience may degenerate into soulless submissiveness to authority. When this happens, the dynasty (the state) ${ }^{17}$ may continue with the help of force but dwindles in substance like body lacking nourishment. ${ }^{18}$

The possibility of non-conformity between governmental laws and Islamic law had worried Ibn Khaldun. He comments that "governmental and educational law destroy (human) ${ }^{19}$ fortitude because their restraining influence is something that comes from outside. The religious laws, on the other hand, do not destroy fortitude, because their restraining influence is something inherent" 20 (i.e. something which is based on faith and belief) ${ }^{21}$ Apparently, it implies that governmental laws cannot be made meaningful and effective without their being compatible with Islamic laws.

The question of social solidarity, which is central in Islamic society as founded by Prophet Muhammad (s.a.w.) in Madina, is tied up with the question of social justice and collective social responsibility. Both the Quran, and the Sunnah and Hadith have inspired potent thoughts on the question.

\section{On Social Justice and Collective Social Responsibility:}

In Islam man and his society is inseparable. The religion in its principles and practices, is as much focussed on the individual as on the society. "The Quran places every person under obligation to safeguard and promote the welfare of his own soul as well as the welfare of his fellow being",22 observes

\footnotetext{
${ }^{16} \mathrm{Ibn}$-Khaldun, p. 250

${ }^{18}$ Ibn-Khaldun, p. 248.

${ }^{20}$ Ibn-Khaldun, p. 96-97.

$17,19,21$ Parent

Parentheses are the author's own.

${ }^{22}$ M.Z. Khan, Islam: its meaning for modern man (London 1962), p. 128.
} 
Sir Zafrullah, an eminent Muslim Jurist of this century. In his view, other than the sacrosanct covenant which is sealed with the Supreme Creator, man's earthly covenant is with his society, the society of peace through sharing and caring. The social solidarity which has been a principle concern in Islam is meant to be achieved through a righteous, just and equal society. Prophet Muhammad (s.a.w.) in his last speech decreed the foundation of an equal social order:

Each Muslim is a brother of another..... An Arab has no superiority over a non-Arab......Be fair to your slaves, give them to eat what you eat and to wear what you wear..... You have rights over your wives as much as your wives have rights over you etc.

One of the principal mechanism of ensuring an equal society lies in the economic system envisaged in Islam. Through its economic institutions such as Zakat, and the Laws of inheritance, Prohibition on riba, monopoly, hoarding, short-weight etc. as well as through moral exhortation on the economic behaviour of man in society, Islam provides the framework to secure the widest and the most beneficient distribution of wealth. Quoting from the Quran (59:8), Sir Zafrullah asserts that "wealth must remain in constant circulation among all sections of the community and should not become the monopoly of the rich." ${ }^{23}$ However, unlike the contemporary doctrine of communism, Islam does not prescribe peremtory equality in the distribution of wealth, for it is unrealistic in so far as it would negate the diversity of individual talents and capacities and thereby would deny the varying rewards from the Supreme Master.

On the other hand Islam does not approve of free and unrestrained economic competition and the corresponding rewards to work itself out on the basis of market forces, as assumed in capitalism, for that too would lead to unfairness and economic brutality which would destroy the moral and spiritual fibre of the society as a whole.

The erudite scholarship of Sir Zafrullah makes one see that in Islamic social system vis-a-vis economic system rights and duties, obligations and injuctions are always balanced, and are made supplementary and complementary. He observes that "the right of possession, enjoyment, and transfer of property, is recognised and safeguarded in Islam, but all ownership is......subject to the moral obligation that in all wealth all sections of the society, and even animals have right to share (at Qur'an 51:20). Part of this obligation is given legal form and is made effective through legal sanction, but the greater part is secured by voluntary effort put forth through a desire to achieve the highest moral and spiritual benefits for all concerned." ${ }^{24}$ Sir Zafrullah's analysis and presentation clearly suggests that the principal economic right

${ }^{23}$ M.Z. Khan, p. 151.

${ }^{24}$ M.Z. Khan, p, 150. and obligations in Islam are such that if meticulously followed, those would as a whole. In fact one foster highte meaning of "Ownership in Islam" observes another non-Muslim researcher, "is a social function, and is interpreted in Islamic law as aiming at the community.",26

Islam, for the first time ever in the world pioneered the effective concept of a welfare-state in so far as it has laid down as a duty of the state cept of a weffare-state in so fitizens. ${ }^{27}$ History tells us to provide the minimum necessities of life for all citizenls. census was carried that during the Khalifat of Omar (r.a.a.) the frst regurar census wic necessities out in order to ensure that every citizen was supplied with the basic necessities in food, water and shelter.

In support of the welfare state based on economic equality and social justice for all members of society as visualized in Islam, Syed Qutb, one of the prominent Muslim thinkers of this century on social justice, argues for the prominent Muslim thinkers of state welfare focussed redistribution of wealth from the a prestion fres distribution of land to the poor. ${ }^{28}$

The concept of social justice embedded in the 'Arab Socialism' of con(eften temporary an influence of Marx or Lenin. However, some author ${ }^{29}$ have sugvewed as an influence of Marx or Lenion'. lie deep in the socio-religious history gested that the roots of 'Arab Socialism' lie deep in social relations pattern. of Islam society and its early social structure and social reial emancipation From the view point of these authors, the impulse of social emancipation leading to equality of men, and thereafter servitude to only One Supreme Authority, is not derived from the slogan of Marx but from the gospel of Muhammad (s.a.w.)

\section{On Rights of the Society and Rights of Individuals:}

In the question of individual rights and community rights, nations seem to encounter an inevitable enigma. In the Protestant Capitalist belief individual right is protected and propagated so as to often encroach upon coldive otherhand, ective societal welfare. Atheistic Communist belief The so-called the 'Freedisregards the individual for the sake of societal good. The so-calom, political World' appears to champion the cause of economic freedom, poitical

\section{${ }^{25}$ M.Z. Khan, p. 151.}

${ }^{26}$ C. Waddy, The Muslim world (London, 1976), p. 43.

${ }^{27}$ M.Z. Khan, op. cit., p. 161.

${ }^{28}$ Social justice in Islam, translated by J.B. Hardie (Washington, 1953), p. 49-59.

29 . ${ }^{29}$ Abdel Moghney Said, Arab sociatism (London, 1972), Mits social thoughts in contemporary

the desert (London, 1975); Kamal (London, 1968); Hannah \& Gardner, Arab socialism (Leiden, 1969). 
freedom and freedom of thought. Ironically, however, freedom to acquire wealth has been paralleled by slavery of poverty, political freedom and freedom of thoughts has led to atomization and schismatization of societies and institutionalized violence.

The possibilities of such schism is obviated in Islamic social thoughts. Islamic social teachings most frequently have double bearings always supplementing and complementing. Collective societal interest and individual interest are inter-woven and mutually supplementary and complementary. The Prophet (s.a.w.) said..... 'the believers in their mutual compassion, sympathy and love are like the human body, if one of its organs falls ill, the remainder will suffer.' This principle was gloriously implemented in the civic law during the Khalifat of Omar (r.a.a.) who decreed that 'if a person dies of starvation, the penalty of wrongful death should be imposed on all the citizens of the town as though they had killed him. ${ }^{30}$

Within the comprehensive concept of Divinity and of the Universe, of life and humanity in Islam, societal code of conduct is meant to comply with the ordained and well-explained forms of mutual love and respect, mutual cooperation and mutual responsibility between man and man, between man and his society. In this respect Syed Qutb maintains that 'just as encroachments upon society by the cupidity and ambition of the individual are a kind of social oppression which is inconsistent with justice, similarly encroachments upon the nature and ability of the individual by society are also a kind of injustice. When the social system vouches for the rights of the comunity in the efforts and abilities of the individual and lays down curbs and limitations on the freedom, the desires, and the ambitions of the individual, it should not therefore, ignore the rights of the individual within the limits which safeguard the welfare of the community and of the individual, and which prevents his actions from coming in conflict with high objectives of life, ${ }^{31}$ Islamic tenets are thus seen as conscious enough of the need for individual freedom and its harmonization and integration with collective community freedom. 'Freedom of action' holds Syed Qutb, 'should be given to both the individual and society without any mutual conflict; and that people, one and all, should work together for the growth and progress of human life, for all are bound by one laws which has but one aim'. ${ }^{32}$ It follows, therefore, that in societal management and administration choice and freedom can, and should, be provided while scope of excesses and encroachment on other's must be foreclosed so that one man's freedom of choice does not become another man's obstacle to freedom of choice.

${ }^{30}$ C. Waddy, op. cit., p. 39.

${ }^{31} \mathrm{~S}$. Qutb. Islamic approach to social justice in Islam: its meaning and message, edited by Kurshid Ahmad. (London, 1975), p. 127.

${ }^{32}$ S. Qutb, p. 124.
Islam admits realistically that human souls are prone to avarice (al-Quran 4:128), and that man can, even be neggardly (al-Quran 17:100). Islam therefore enjoins man to believe that as he has freedom of choice, he may go astray; he therefore needs guidance so that he may know how to realize his own true greatness. ${ }^{33}$

\section{On Authority \& Responsibility:}

The two-sided bearings of Islamic tenets stand prominent in matters of authority and administration. In Islamic thoughts authority and responsibility are seen inseparable - they are like the two sides of a coin. The fourth Khalifa Ali is quoted to have sent instructions to his Viceroy in Egypt in the following words: "Fear Allah, in regard to the lowest class in society, who are helpless, poor and miserable. You are responsible to Allah, for He entrusted them to you. The distant should receive as much as those who are near. Give each his due...... you will not be forgiven if you ignore minor matters to concentrate on those which seem important. Look into the affairs of those who are so weak that they cannot reach you...... The burden of responsibility on a viceroy is indeed very heavy one." 34 Khalifa Omar is also known to have once said..... If a mule stumbles in Iraq (far away from the seat of administration), I shall find myself responsible to Allah for it on the day of Judgement for why had I not paved the road properly?' These are some of the examples of the thoughts of early Muslim leaders on the dualistic implication of authority and responsibility.

The highest order of socio-political organization as envisioned in Islam is a global confederation of autonomous states for the maintenence of peace and cooperation in promoting human welfare throughout the world. However, at every other lower levels beneficient administration of societal affairs is clearly the directive. As for the nature of socio-political organization, the Quranic mandate is as follows: "Verify, Allah commands you entrust authority in to the hands of those who are best fitted to discharge it..... and when you are called upon to judge between or excercise authority, you do so equitably and with justice." (al-Quran 4:59-66). It is clear that while people have a sacred duty to excersice rational judgement to choose 'the fitted' to discharge collective social responsibility, those chosen, on the other hand, also have a sacred trust to exercise their authority equitably and with justice. Such are the notions of checks and balances in the relationship between people and their earthly protector, guide and adjudicator.

Similarly, the hierarchical nature of responsibilities and accountabilities are also spelled out by the Prophet (s.a.w.) when he says....." Everyone of you is a shephard, and everyone of you is accountable for that which is com-

${ }^{33}$ Islam: its meaning and message, edited by K. Ahmad (London, 1975), p. 25-26.

${ }^{34}$ C. Waddy, op. cit., p. $43-44$ 
mitted to his care" - implying that the head of the state is responsible and answerable for his people, every head of household is responsible and accountable for the members of his family, every woman is responsible and accountable for her home and children, and every servant is responsible and accountable for the property that is in his charge.

\section{On Social Organization \& Leadership:}

The scheme of human life and living in Islam is meant to revolve around the central concept of Oneness (Tawhid). It is made clear in the Quran that the Universe, which is in fact unified beyond common perception, has emanated from the Single Will, so that humanity owes an essential unity of purpose. Apparently Islam recognizes the instance of differential race, colour, language, and economic group; but it is cryptically suggested that this diversity is part of the 'Grand Design' so that it would stimulate more meaningful interaction: ("You have been made into nations and tribes so that you may know one another"'; Al-Quran (49:13). Seen in this light diversity is a system of great opportunity where social intercourse and interaction can be heightened. In fact this is an opportunity to train in the art of cooperation and harmonious living. Sir Zafrullah enthusiastically notes that a whole set of directions in the Quran and Hadith exhort mankind not to set up artificial barriers in the way of free social intercourse. 35

Islam clearly aims at merging all sections of the society into an organized and integrated single community. In view of this towering goal in Islam, Ibn Khaldun, the forefather of sociology, spoke on the need for social organisation. In fact Ibn Khaldun views social organization as synonymous with society and civilization and asserts that there can be no society or civilization without social organization. He suggests that at the helm of social organization there must be leadership who would exert restraining influence on the society. Such leader should combine divine law and rational politics for the sake of ultimate good of man and his salvation hereafter, as well as for man's safety and well-being in this world. As a pragmatist scholar, Ibn Khaldun rejected the prevailing non-muslim philosphical schools of thought, and asserted that the debate on politics of societal interest and the interest of the ruler is redundant and irrelevant since these two areas are inseparable according to Islamic principles. He approves of political norms that are natural in social organization, together with necessary concern for strength and group-feeling. ${ }^{36}$

For a high order of social organization cohesive neighbourhood are like the essential building blocks - small masses unite into larger masses, larger masses unite into even larger masses. This organic principle of social organiza-

${ }^{35}$ M.Z. Khan, op. cit., p. 147.

${ }^{36}$ Ibn Khaldun, op. cit., p. 256-257. tion is well recognized in Islam in so far as the Quran lays great stress on kindness towards neighbours (surah 4:37), and the Prophet counsels that one should be willing at all times to share with ones neighbours. The Prophet of Islam lays so much importance on social solidarity at the grass-roots that he once said that a believer who goes to sleep with full stomach while his neighbour is hungry, is not really a believer. On this matter of 'neighbourhood-'Asabiyah', Ibn Khaldun theorizes that if the direct relationship between persons who help each other is very close, it would lead tionship between persons who help each other is very close, it would lead this kind of 'Asabiyah which gives a group protection and makes possible this kind of 'Asabiyah which gives a group protection and makes possible mutual defence, pressing of claims, and every other kind of social activity Al Ghazali says 'Iman is the reward for fellowship, while Islam is the reward for neighbourliness. The distinction between the excellence of Iman and exfor neighbourliness. The distinction between the excellence of Iman a distinction between the diffich of fulfilling one's difficulty of fulfilling one's duty as a neighbour and that of fulfilling one's duty in fellowship. To prove his point, Ghazali quotes the Prophet as saying 'Be a good neighbour to your neighbour and you will be a Muslim; 'Be a good fellow to your companion and you will be a Mu'min. ${ }^{38}$ One naturally wonders whether the contemporary social science has anything more to offer in respect of neighbourhood and neighbourhood planning that what has been said hundreds of years ago in Islamic society and culture.

In matters of neighbourhood social affairs as well as other public af(Al-Quran 42.38). This is meant to be a characteristic feature of an Islamic Communi42:38). This is meant to be a characteristic feature of an Islanic Communis ty. Consultation implies cooperation which together involve associatic is the heart and core of 'Consultative democracy' which the modern world is the heart and is so ardently trying to preach. Sir Zafrullah quotes Ayat 115 of Sura 4 to point out that Islam recommends three types of public association - First those for the purpose of promoting the general welfare, second, those the the spread and propagation of knowledge; object of which is to promester and third, those established for the purpose and for removing causes of fric

\section{On Family Stability as the cornerstone of Social Stability:}

Long before the emergence of modern social science and sociology, Islam saw the human institution of family as the basic unit of society and socia saw the human institution of famile super-structure organization. If the family institution is shaken, the whole super-structure

\footnotetext{
${ }^{37}$ Ibn Khaldun, p. 98, 107.

${ }^{38}$ Al-Ghazali, op. cit., p. 53-54

${ }^{39}$ M.Z. Khan, op. cit., p. 148.
} 
of society tends to crumble. Divorce and separation which breaks up family, as the contemporary world would testify, is seen in Islam as a dangerous practice, and hence has discouraged it strongly. With a view to save marriage and family, men in Islam are reminded that..... 'if you dislike the wives, it may be that you dislike something wherein Allah has place much good' $(4: 20) \ldots . .$. Sir Zafrullah quotes the Prophet to have said that of all the things permitted, the most obnoxious in the sight of Allah is divorce. ${ }^{40}$ Clearly, saving a family unit is of paramount concern in Islamic Society. Ibn Khaldun maintains that 'Asabiyah is as much a fruit of a group consciousness as of continuity of lineage. In fact the nucleus of 'Asabiya in his scheme of social cohesion is formed at the family, and for that matter a strong and respectable family around which other families attach themselves in a process of organic unity. ${ }^{41}$

To bring up a healthy resourceful and righteous society the parental duties in a family are no less significant. The Quran commands 'Do not destroy your off spring' (sura 17:32); one inner meaning of this commandment is that 'do not destroy their faculties, do not allow them to be spoilt.' The Prophet says.....'Honour your children.' implying honour them so that they learn self-respect and mutual respect. Both these instructions taken together should yield the highest principles of socialization. In this modern day of contradictory theories in child-psychology and child upbringing, there is no need to be confused, for Islam and its Prophet (s.a.w.) have long since provided the wisest guidelines in child upbringing and counselling. - While the Prophet stressed on the virtue of kindness and affection to children and treating them all with tenderness, he did not approve of undue indulgence. In order to inculcate the spirit of self-respect and self-reliance, two most crucial virtues unanimously advocated by modern educationists, the greatest educator in Islam had laid it down as a rule for himself, his family and his descendants, not to accept charity.

\section{On Environmental Protection}

Islam being the last and the perfect gospel for human life and living, it is hardly surprising that such recent social crisis as environmental pollution is not beyond the purview of the wisdom of Islam. The cosmic outlook in Islamic teaching makes man integral part of the living system around him, of which he is also the viceroy. Modern ecologists and development sociologist are only 'rediscovering the gun-powder' as it were, in saying that one must study the environment as a complex unity in which everything is inter-related with everything else. Conceptualization of such organic unity is possible only in the presence of a unifying spritual principle which lies at the heart of Islam.

${ }^{40}$ M.Z., Khan, p. 143.

${ }^{41}$ Ibn Khaldun, op. cit. p. 98-102.
The more enlightened of ecologists would add that the web of inter-relatedness encompasses the psychological and spiritual levels and ultimately with the source and origin of all things. All these and many more have been said long long ago in the Divine Message.

The concept of bilateralism as in all other spheres of life in Islam is implied in man's relationship with nature also. The bounty in nature is for man to enjoy but he must also protect it from danger and destruction. Instead of the Divine Responsibility of shepherding the natural bounty, man has become the plunderer of it. Instead of being a trustworthy steward, man takes out whatever and whenever he wants from nature. Dr. Syed Hossein Nasr, an accomplished scientist from Harvard University and a profoundly learned Muslim scholar, sees the solution in abandoning the anthropomorphic (man-centred) approach to nature and life, and readopting the cosmic approach and the Divine Order, which has been the fountainhead of the most original science and technology. Unless this fundamental cosmic view, as in Islam, is put right, there is no hope of peace and little prospect of survival, warns Dr. Nasr. ${ }^{42}$ In more philosophical tone he continues.... 'To destroy the natural environment before the altar of man's passions means to sacrifice the inner man for the human animal which is nothing but the most externalized aspect of the totality of man......Ecological crisis cannot be solved without turning to the spiritual dimension of the problem which many try so hard to overlook. ${ }^{43}$

\section{Concluding Remarks:}

It is a bounden duty of any Muslim scholar to correct the world and say that the highest ideals of human development and social development did not originate in the works of Rousseau or the French Revolution; those ideals are a monumental and eternal contribution from the Islamic Revoluideals are a mon fourteen hundred years ago. Not only that, in a cosmic approach, combining science and metaphysics, Islam gave expression not only to the fundamental truth that lies in the nature of things but also an earthly solution essential for the welfare of human society. This is manifest in the remarkable developments of astronomy and mathematics, algebra and physics, chemistry and medicine, philosophy, sociology and economics in early Islamic civilization The works of Muslim scholars like al Ghazali, al Biruni, Ibn Sina, Ibn Rushd, Ibn Jubair, Ibn Khaldun, and Ibn Batuta provided invaluable stimuli to the thinkers of the European Renaissance period.

Unfortunately, however, the wholeness of life and unity of outlook and purpose, which had been the cornerstone of science and technology at the

${ }^{42}$ The encounter of man and nature (London, 1968).

${ }^{43}$ Western science and Asian cultures (New Delhi, 1976), p. 36. 
hands of the early Muslim scholars, was lost in the process of transfer to medieval European scholars. Subsequently, the progeny of European Renaissance i.e. the modern science and technology became defective in so far as thoughts, knowledge, and purpose of life have been fragmented and compartmentalized. True, a great deal have since been achieved in the domain of material life, but at the cost of ignoring the knowledge of the whole reality which surrounds man every movement of his life.

A large part of the Islamic world from North Africa to Indonesia came under European colonial rule just at a time when science and the industrial revolution in Europe was making great strides in material progress. This combination of events reinforced the aggresive colonialist's sense of superiority, and with the same stroke injected an unfounded feeling of inferiority amongst the colonized Muslims.

I believe, Islam has an inner capacity of renewal - it lies in the 'Asabiyah. The Initial 'Asabiyah led to the fostering of a great civilization. At intervals, the faith has raised reformers to revamp the light of civilization. Now the Umma has a good chance, better than any other world community, to overcoming the problems of human existence and peaceful survival through rejuvenating its concept of unity in its totality and it's power over human will and sence of purpose.

\section{References}

AL-GHAZALI. On duties of brotherhood, translated by Muhtar Holland. London: Islamic Foundation, 1975.

BIANCO, Mirella. Gadafi: voice from the desert. London: Longman, 1975. GAUHAR, A. The challenge of Islam. London: Islamic Council of Europe, 1978.

HANNAH \& Gardner. Arab socialism. Leiden: 1969.

Ibn-KHALDUN. The Muqaddimah: an introduction to history, translated by Franz Rosenthal. London: Routledge, Kegan \& Paul, 1967.

ISLAM: its meaning and message, edited by K. Ahmad. London: Islamic Council of Europe, 1975.

KARPATI, Kemal H. Political and social thoughts in contemporary Middle East. London: 1968. , 1968.

KHAN, M.Z. Islam: its meaning for modern man. London: Routledge, Kegan \& Paul, 1962.

NASR, Seyeed Hossein. The encounter of man and nature. London: Allen \& Unwin, 1968.

- Western science Asian cultures. New Delhi: Indian Council for Cultural Relations, 1976.
QUTB, Sayyed Islamic approach to social justice in Islam: its meaning and message, edited by Khurshid Ahmad. London: Islamic Council of Europe, 1975.

—. Social justice in Islam, translated by J.B. Hardie. Washington.

1953.

SAID, Abdel Moghney. Arab socialism. Dotset: Blandford Press, 1972.

WADDY, C. The Muslim world. London: Longman, 1976.

WATT, W.M. Islam and the integration of society. London: Poutledge, Kegen \& Paul, 1961 